\title{
Korean-Origin Kindergarten Children's Response to African-American Characters in Race-Themed Picture Books
}

\begin{abstract}
So Jung Kim
Department of Teacher Education, The University of Texas at El Paso, Education Building, Room 801B, 100 University Avenue, El Paso, TX 79912, USA
\end{abstract}

Correspondence should be addressed to So Jung Kim; skim7@utep.edu

Received 3 April 2014; Revised 1 July 2014; Accepted 15 August 2014

Academic Editor: Stephen P. Heyneman

Copyright $\odot 2015$ So Jung Kim. This is an open access article distributed under the Creative Commons Attribution License, which permits unrestricted use, distribution, and reproduction in any medium, provided the original work is properly cited.

\begin{abstract}
In spite of the contributions of previous studies about multicultural education, children's literature, and teaching for social justice, no study had investigated their intersection. This qualitative case study explores how kindergarten-age Korean children respond to African-American characters in picture books during read-alouds. The data were collected by audio-recordings, open-ended interviews, children's artifacts, and observational field notes. One of the findings was that the children exhibited resistance to black characters, and their resistance was shaped within their larger social and cultural surroundings such as the parents' racial views towards black people and the dominant racial discourse of Korean community. Findings suggest that the goal of a literacy program in bilingual children's classrooms has to be that students learn not only about biliteracy skills but also about the value and meaning of the human experience in our pluralistic society.
\end{abstract}

\section{Introduction}

Children start to understand racial differences from an early age [1-3]. According to Van Ausdale and Feagin [4], "Children as young as three and four employ racial and ethnic concepts as important integrative and symbolically creative tools in the daily construction of their social lives" (page 26). Eder [5] also claims that preschool children understand racial differences by distinguishing themselves from other racial and ethnic groups. As a pedagogical tool for teaching children racial, ethnic, and cultural diversity, many teachers and researchers highlight the significant role of multicultural literature [6-11]. These professionals argue that multicultural literature provides children with opportunities to understand the ethnic and cultural diversity that they meet as a part of their daily experiences. Most recently, a growing number of researchers have paid attention to the role of children's literature that deals with race themes (e.g., [12-15]). The existing studies provided important insights into the important role of race-themed picture books in young children's classrooms. Yet, since all of these studies were conducted in school-aged children's contexts, there is still a startling paucity of studies examining how picture books with race themes can be incorporated in preschool and kindergarten (Pre-K) classrooms. The search for previous studies is particularly challenging in bilingual contexts.

Discussing Race in Bilingual Classrooms. Bilinguals confront a variety of barriers in public and private schools [16-19]. For example, bilingual students have limited opportunities to receive quality instruction because a large number of minority students go to schools located in indigent districts [19]. Their challenges can also include cultural conflicts between the school and home [16] and the lack of sufficient curriculum materials in two-language surroundings [17]. In addition, language minority children often experience racism "on a daily basis in the form of jokes and/or derogatory gestures and comments ... based on their physical appearances" [20, page 133]. Marx [21] argues that these "racialized experiences" (page 119) are dangerous since they can hurt students' linguistic, cultural, and racial identity. Although many scholars have pointed out a continued need to understand racialized practices within early childhood settings [22, 23], race issues have rarely been investigated within bilingual contexts, because most early bilingual/biliteracy studies focused on vocabulary acquisition or sentence construction (e.g., [2426]). In particular, nothing has been documented about bilingual Korean children's racial attitudes towards African 
Americans. The lack of previous studies becomes problematic when considering the historical context of relationships between Korean Americans and African Americans.

Relations between Koreans and Blacks. In spite of fast-growing numbers of foreign residents in the last ten years, Korea is still one of the most ethnically homogenous nations in the world [27]. Of these foreigners, African Americans comprise an extremely small percentage, and the Korean government does not even have definitive numbers for them (see [28]). Given this context, the only tools for Koreans to learn about African Americans are mass media such as Hollywood movies, Korean television shows, newspapers, and the American Forces Korean Network [29]. However, as media sources often depict blacks as criminals, drug dealers, and rapists [30], many Koreans have developed negative attitudes towards them. For instance, Korean high school students ranked black people highest in categories like laziness and aggression and lowest in categories like diligence and hygiene [31].

In fact, the Korean people's negative views towards African Americans have been aggravated in the last few years due to some incidents in Korea. According to the Korean Joongang Daily [32], a 24-year-old African-American teacher struck a 61-year-old man in the face and threatened him in a bus. As several video clips were taken by passengers and appeared on major web sites, many Korean people were offended. The man's behavior was especially unacceptable in Korean culture because of the heavy influence of Confucianism, which teaches respect for elders. There was another incident in 2010 in which a 26-year-old African-American teacher of English to elementary school children posted a video of himself having sex with a Korean girl. Despite his illegal activities, he did not receive any punishment but simply left the country [33]. The reporting of such incidents in the media has contributed to negative racial attitudes of Koreans towards blacks.

Prejudice towards African Americans persists among not only Koreans but also Korean Americans, particularly in the first-generation. Asante [41] argues that Korean immigrants already had a high degree of white racism before coming to the USA due to the racial hierarchy of whites in the media. Also, several tragic events that occurred during the 1980s and 1990s, including the L.A. riots and other shooting incidents, caused more tensions between the two racial groups [29]. Influenced by this historical context, KoreanAmerican children rarely socialize with blacks [42]. Min [30] points out this problem as follows:

Just like their parents, the problem in the relations between African-American and Korean-American children is that there are little or no real human relations between them. Their relations or interactions are largely unknown and hidden. They may develop their own systems of negativism and prejudice (page 3).

However, there is a noticeable silence in literacy research around issues of race and racism in Korean/KoreanAmerican contexts. Given this imperative, this qualitative case study explores how kindergarten-age Korean children respond to African-American characters in picture books during read-alouds. With a qualitative case study approach, the current study focuses on the reading of six KoreanEnglish bilingual children in Ms. Park's classroom in the Korean Language School (KLS). The study addresses the following two research questions.

(i) How do the bilingual Korean children respond to literature depicting African-American people, and how do literary discussions influence their racial attitudes toward blacks?

(ii) How is the children's racial identity situated within the context of white privileges, and how do race-themed books affect their self-concepts?

In this study, the race-themed picture books include books that deal with issues such as racial diversity, interracial friendships, racial segregation, discrimination, freedom, and racial equality. Also, in defining racism, the study adopts Kubota and Lin's [43] notion that racism is "both discourse and social practices which construct and perpetuate unequal relations of power through inferiorization" (page 6). By investigating two research questions, this study aims to provide insight into how literacy teachers can use children's literature to create environments in which young bilingual children can develop a critical awareness of race. The fundamental goal of this study is to pursue educational equity and equality by providing a more democratic vision for teaching and learning literature in young bilingual children's classrooms.

Theoretical Frameworks. The study is situated within two theoretical frameworks that offer critical approaches to literacy education. First, the study was informed by reader response criticism. Many reader response theorists claim that reading involves the interdependence of the individual and the community (e.g., [44-46]). Beach [44] argues that students' responses are constructed within a complex social/cultural context according to their social roles and their membership in their particular interpretive communities. Culler [46] also points out that readers' social roles and interaction in a particular context constitute their responses to literary texts. Because readers' responses to literature are socially constructed through their social interaction during a reading activity, "texts, readers, and contexts are each inseparable from the other" [47, page 66].

In addition, Critical Race Theory (CRT) was used as the guiding framework for understanding children's racial identity formation in relation to whiteness. According to Compton-Lilly [48], racism is ingrained in ordinary activities, and it is often "invisible and is treated as normal in American society” (page 6). As an everyday occurrence for people of color, racism creates structural disadvantages that impact individual and community well-being $[49,50]$. Goodman and West-Olatunji [51] argue that systemic racial oppression permeates all education settings. Familiar practices within early childhood classrooms normalize racist attitudes, and race-based actions that underpin normalized school practices continue to shape the educational segregation of young children [22]. Since racism surfaces in American schools in a myriad of ways, it is important to understand how race 
is inextricably tied to young children's daily life and how "whiteness" affects schooling in tangible ways [23].

CRT also provided important insights into how race operates in language and literacy practices. Kubota and Lin [43] argue that one manifestation of systemic racism is evident in the historical construction of language and literacy. Race is often intertwined in complex ways with culture and language [52]. The "interconnectivity" between race and language has been addressed by many scholars in the field of Teaching English to Speakers of Other Languages (TESOL) (e.g., [43, 53, 54]). For example, Kubota [54] argues that English language education should be understood within the context of power, subjectivity, and social justice. Liggett [50] emphasizes how the notion of "intersectionality" (page 112) between linguistic identity and racial membership surfaces for English language learners (ELLs) who routinely encounter discrimination based on language proficiency and accent. These studies highlight the important role of race in language/literacy teaching and learning and key intersections between CRT and English language learning.

Race is also deeply implicated in an ideology of literacy as "a source of potential social engagement and critique" [55, page 176]. van de Kleut [56] claims that the teaching of literacy is not a neutral practice, since classroom dynamics and educational practices are influenced by racial discourses and relations of power. Therefore, literacy education in schools should address race, racism, and antiracism to prepare children to inspire democratic attitudes and appreciate racial differences [23]. The study employed CRT to investigate racialized literacy practices and situated representations of racism in an early childhood bilingual classroom. It also provided a framework to understand how racism in early childhood literacy practices expands beyond the acts of individuals. Based on CRT, the study approaches reading practices through the perspectives of systematic racial inequality and racial privileges. Individual identity is also seen within the broader contextual factors as "an assemblage of positions, narratives, and discourses constructed from relationships, experiences, and individual positionality" [50, page 118].

\section{Methods}

This study employed a qualitative case study approach in order to attain in-depth contextualized understanding of the students' interactions with the texts. An intensive contextspecific investigation was also necessary to capture the children's rich voices and "the nature of experiences" [57]. The data were collected for six months by audio-recordings, open-ended interviews with the children, their parents, and the teacher, children's artifacts, and observational field notes. Among them, interviews were one of the important data sources: formal interviews were conducted in Korean with parents (four times, fifteen minutes each) and the teacher (five times, thirty minutes each) to have in-depth understandings of their racial attitudes towards African Americans and their views towards multicultural education. Although interview questions were created in advance, the researcher often asked several follow-up questions based on each participant's answers.
In addition, field notes were created with as much description as possible, including feelings and physical expressions of participants: the total hours of transcription collected during the observation period were 3200 minutes. In addition, children's drawings were also used as key artifacts for this study. After collecting the children's artifacts and some related materials, the researcher created portfolios to keep track of the children's written texts and their conversations related to those texts.

In order to analyze children's responses to the books, Emerson et al.'s [58] coding methods were adopted. First, by adopting a preliminary coding method, the researcher transcribed the children's conversations, their oral responses to the books during the read-aloud sessions, and interviews with the parents and the teacher. Then, using analytic coding, the researcher categorized each literacy activity and a series of episodes and subcategorized them based on themes such as race, gender, culture, prejudice, injustice, fairness, family, segregation, equality, equity, resistance, freedom, and friendship. In addition, each participant's emotional responses such as anger, disgust, pleased, painful, and resistance were categorized. After that, some of the literacy events were selected based on the research questions aforementioned. After identifying the focal activities, the researcher reviewed the completed set of notes to capture some important changes in the field over time.

2.1. Setting. The setting for this study was Ms. Park's classroom at the KLS in the Midwestern United States, which was one of 1,021 Korean Heritage Language Schools in the USA [59]. Classes at the KLS began at 10:20 in the morning every Saturday, with each class session lasting for 3 hours. Of twelve classrooms at the KLS, Ms. Park's classroom was observed because Ms. Park read multicultural literature to her students. She also had race-related talks with her students during various literacy activities. The focal literacy activity was "Story Time," which occurred from 11:40 am to 12:20 pm every Saturday. During this session, Ms. Park read aloud multicultural literature in a whole group and talked about the story with her students using both Korean and English.

There were six children at Ms. Park's classroom at the time of the study, and all of them participated in the study. Most of them were five years old and their ethnicity was either Koreans or Korean Americans. They spoke both Korean and English, although their dominant language varied. Table 1 demonstrates the backgrounds of each participating child (note: in order to protect the privacy of participants, all names are pseudonyms).

Ms. Park was a former teacher who majored in art in Korea. She received her master's degree in the United Kingdom and relocated to the USA seven years ago. She joined the KLS in 2011, and since then she had taught the Korean language and culture to preschoolers. In terms of the teacher's racial concepts, she considered herself as an Asian (a Korean), and her racial attitudes towards blacks were very positive. In the interview with the teacher, Ms. Park indicated that she became interested in African-American people/culture due to her positive experiences with an African-American family in the UK. Among diverse social issues including gender, class, 
TABLE 1: Description of each participant.

\begin{tabular}{lccccc}
\hline Name & Gender & Age & Ethnicity & Family backgrounds & Dominant language \\
\hline Grace & Female & 5 & Korean-American & Parents \& one younger & brother \\
Jimmy & Male & 6 & Korean & Parents \& one younger & Korean \\
Katie & Female & 5 & Korean-American & Parents \& one older brother & English \\
Sam & Male & 5 & Korean-American & Parents \& one older sister & Korean \\
Sue & Female & 5 & Korean-American & Only mother & English \\
Young & Male & 5 & Korean-American & Parents \& one older sister & English \\
\hline
\end{tabular}

(Note: Jimmy was six years old, but he was enrolled in kindergarten.)

sexual orientation, and religion, she was especially interested in racial issues, as she noticed many Korean people's negative racial attitudes towards people with dark skin, particularly African Americans and Southeast Asians. Ms. Park also informed us that in spite of her strong belief in the importance of teaching racial/ethnic/cultural diversities, she had never incorporated multicultural literature into her curricula because of her lack of experience with teaching multicultural material and the absence of multicultural literature written in Korean. Discovering that she shared a mutual interest with researcher in teaching racial, ethnic, and cultural diversities to young children, Ms. Park joined the project.

Ms. Park read a total of twelve multicultural books during the observational period, and she selected all of these books in collaboration with the researcher. Among them, this study focused on the seven books shown in Table 2 .

Those books were selected because they depicted AfricanAmerican people and their culture. They also dealt with racial diversity, interracial friendships, and racial justice issues such as racial segregation, discrimination, freedom, and racial equality.

2.2. Resistance to Black Characters. Sipe and McGuire [60] argue that while reading literature, children utilize their experiences to understand the text, and in this process they sometimes express their disapproval of stories. While reading the books with African-American characters, the children in Ms. Park's classroom exhibited displeasure of books, and this was particularly evident through their resistance to black characters. For instance, when the teacher introduced the cover of 핸리의 자유상자 [Henry's Freedom Box], most of the children resisted the book with sullen faces (Figure 1):

Jimmy: (with a sullen face) I don't like that book!

Teacher: 왜? [Why?]

Jimmy: (quiet)

Young: (pointing at Henry's face) The color (of the boy's face) is kind of weird.

Teacher: (to Young) color 가 weird 해? [So, you think that his color is weird?] 왜 weird 한거 같아? [Why do you think so?]

Young: Because skin color is not supposed to (look) like that!

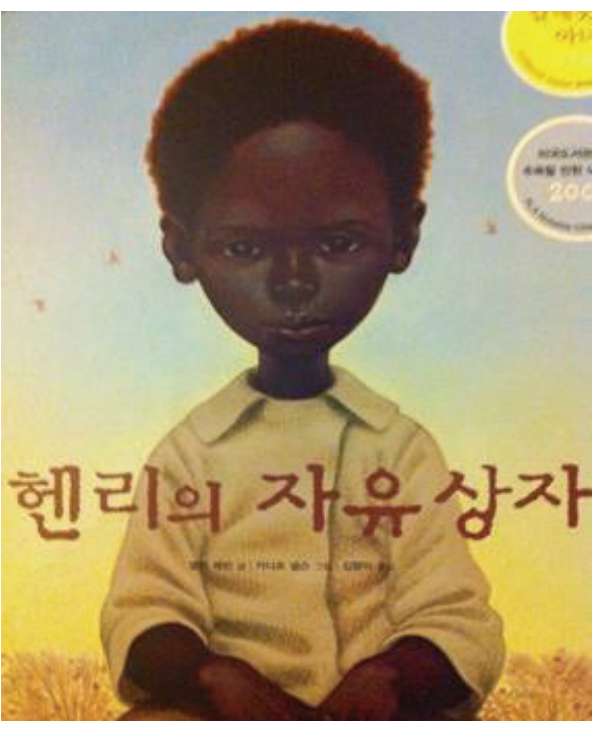

FIGURE 1: The cover of 핸리의 자유상자 [Henry's Freedom Box].

Teacher: 그럼 skin color 는 어때야 되는데? [Then, what do you think that skin color is supposed to be?]

Young: 더 light 해야돼요. [It should be lighter than that.]

Jimmy: (affirmatively nodding).

In the excerpt above, Jimmy exhibited "preferential resistance" [61, page 166] to the text after cursory examination of books. Young also exhibited his unfavorable feelings towards Henry's dark skin, and in doing this both of them used English. It seemed that both Young and Jimmy's resistance to the book was related to their views that dark skin is not a normal skin color. The children's resistance to black characters was also observed when they read the book 그레 이스는 놀라워 [Amazing Grace] [34] (Figure 2):

Sue: (raising a hand) 선생님! 다른 책 읽으면 안돼요? Teacher: 왜? 이 책 싫어요? [Why? You don't like to read this book?]

Sue: (looking at the cover of the book) I don't like her skin color!

Katie: 그리구 ugly 해! [And (she is) ugly]. 
TABLE 2: Selected literature.

\begin{tabular}{lcc}
\hline Title of book & Author & Main themes \\
\hline $\begin{array}{l}\text { 그레이스는 놀라워 } \\
{[\text { Amazing Grace] [34] }}\end{array}$ & Mary Hoffman & $\begin{array}{c}\text { Stereotypes of } \\
\text { racial equality }\end{array}$ \\
\hline $\begin{array}{l}\text { 핸리의 자유상자 } \\
{[\text { Henry's Freedom Box] [35] }}\end{array}$ & Ellen Levine & Freedom discrimination \\
\hline $\begin{array}{l}\text { 인종이야기를 해볼까? } \\
{[\text { Let's Talk about Race] [36] }}\end{array}$ & Julius Lester & $\begin{array}{l}\text { Racial equality } \\
\text { discrimination }\end{array}$ \\
\hline $\begin{array}{l}\text { Chocolate Me! [37] } \\
\text { 사라 버스를타다 } \\
{[\text { Sarah Rides a Bus] [38] }}\end{array}$ & Taye Diggs & Interracial friendships \\
\hline $\begin{array}{l}\text { Tar Beach [39] } \\
\text { 자유의 노래 [The Song of Freedom] [40] }\end{array}$ & William Miller & $\begin{array}{c}\text { Racial segregation } \\
\text { discrimination }\end{array}$ \\
\hline
\end{tabular}

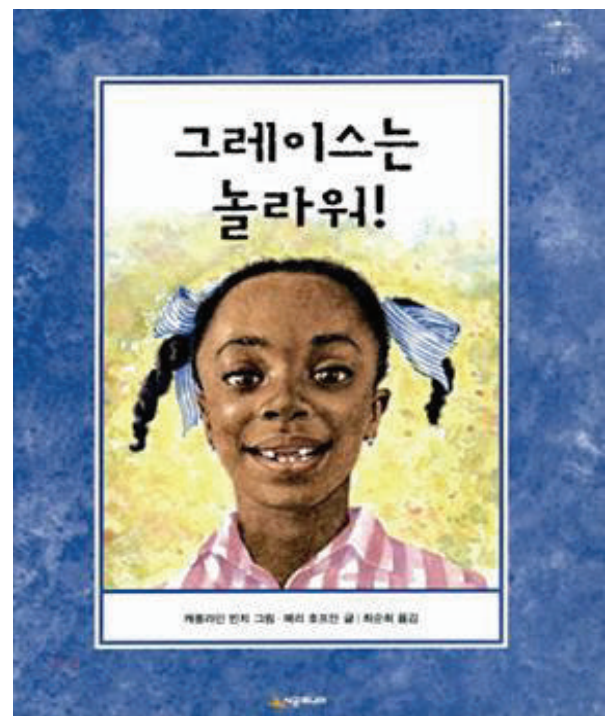

FIGURE 2: The cover of 그레이스는 놀라워 [Amazing Grace].

Like Jimmy and Young, Sue and Katie expressed unfavorable feelings towards black characters, using both Korean and English. Hughes-Hassell et al. [62] argue that children tend to prefer literature that reflects their cultural experiences. The children could find the reading frustrating, as these books did not mirror their own experience and culture, yet their resistance to black characters could also be understood within a broader context of white supremacy. According to Giroux [63], whiteness is a social construct, and it is connected to institutionalized power and privileges that benefit white Americans. For the children in Ms. Park's classroom, race was not a fixed category, since their own racial identity was situated within institutionalized power and white privileges. In US history, blacks have been portrayed as the lower classes through media [42]. In particular, Korean people's racial views have been strongly affected by the racial hierarchy that places whites at the top [41, 42]. Given this racial discourse, most children seemed to consider white people as being superior. Some children were even considering themselves as white or "half white." For example, Katie and Grace included themselves in the category of white people. Young also indicated that he might be "a half-white" because he is "a Korean" and "an American": for Young, "an American" meant only whites. Yet, this did not necessarily mean that they were unaware of their origin as Korean. KLS is an ethnically segregated school, and most of the students were of Korean ethnicity. As the KLS taught the children the Korean language and culture, the children acknowledged their origin as Korean. Yet, when they were asked to explain their ethnic/racial identity, they resisted classifying themselves as "only Korean." Instead, they categorized themselves as "cousins" of white Americans, situating their Korean identity within the larger category of white Americans. Most of the parents also indicated that their children did not seem to consider that they were different from Caucasian peers. The following is the example of this:

Grace's father: Since we are Asian, which means aliens in the U.S., we often asked Grace if she experienced any discrimination due to her skin color at her school. She always responded negatively. I think that she does not consider that she is different from white peers.

The children's categorizing themselves as whites also could be interpreted in relation to the children's parents' social status in the USA. All participating children's fathers had a higher education (a doctoral degree) and had promising jobs. Leonardo [64] argues that racism should be analyzed in relation to classism because class is a tributary of race. Most of the children participating in this study lived in economically privileged and educationally supportive surroundings. In this situation, some children could have subconsciously adopted similar views as the white privileged class.

White-Dominant Surroundings. The children's perceptions towards light skin as "normal" and "acceptable" also could be interpreted in relation to their white-dominant surroundings. Most children attended private schools, and they lived in a white-dominant area. Table 3 summarizes each participant's school demographics. 
TABLE 3: Racial demographics and neighborhood.

\begin{tabular}{|c|c|c|c|}
\hline Name & Classroom & $\begin{array}{l}\text { Race of } \\
\text { teacher }\end{array}$ & Neighborhood \\
\hline Young & All white & White female & White-dominant \\
\hline Jimmy & $\begin{array}{c}\text { Very white-dominant } \\
1 \text { Asian }\end{array}$ & White female & White-dominant \\
\hline Sam & $\begin{array}{c}\text { Black-dominant } \\
6 \text { whites and } 3 \text { Asians }\end{array}$ & Black female & White-dominant \\
\hline Sue & White-dominant & White female & White-dominant \\
\hline Grace & $\begin{array}{c}\text { White-dominant } \\
2 \text { blacks and } 4 \text { Asians }\end{array}$ & White female & White-dominant \\
\hline Katie & $\begin{array}{c}\text { White-dominant } \\
2 \text { blacks and } 4 \text { Asians }\end{array}$ & White female & White-dominant \\
\hline
\end{tabular}

TABLE 4: Parents' racial attitudes towards black people.

\begin{tabular}{lccc}
\hline Name & Racial attitudes to African Americans & Socializing with black people & \multicolumn{2}{c}{$\begin{array}{c}\text { Negative experiences related to } \\
\text { African Americans }\end{array}$} \\
\hline Grace's mother & Slightly negative & Rarely & No \\
Jimmy's mother & Strongly negative & Never & No \\
Katie's mother & Slightly negative & Rarely & Yes \\
Sam's mother & Slightly negative & Rarely & No \\
Sue's mother & Not responded & Not responded & Not responded \\
Young's mother & Negative & Very rarely & No \\
\hline
\end{tabular}

According to Fix and Passel [65], 90\% of the teachers in the USA are female, Anglo, belonging to middle class, and representative of mainstream US society. As seen in Table 3, most of the children's teachers at their schools are whites. Their school populations and their living areas were also predominantly white. In this situation, the children were rarely interacting with African-American children. Sam was the only student who attended the mixed classroom with a black teacher. In the interview with Sam's mother, she indicated that small class size motivated her decision to choose the predominantly black school, rather than a preference for African-American classmates. As he was exposed to blackdominant surroundings, he revealed the least prejudiced views towards blacks during the observation period.

In addition to limited experiences in interacting with black people, the children rarely had the chance to read multicultural literature at home or talk about race with their parents. Most parents indicated that they had never read multicultural books to their children because the children are too young to understand multicultural or racial issues. In these surroundings, the children had very limited experiences with blacks both directly and indirectly.

Parental Influence. The parents' negative attitudes towards blacks also could influence the children's uncomfortable feelings towards black characters. According to Min [30], many Koreans often develop prejudiced notions towards African Americans such as "many of them are drug addicts and alcoholics" (page vii). In the interviews with the parents, most of them revealed negative views towards blacks, although they did not have specific undesirable experiences with African Americans.

As seen in Table 4, most parents presented negative views towards blacks, and they rarely socialized with African Americans. Considering this, the children's negative responses to black characters could be influenced by their parents' racial attitudes to African Americans.

Negative Image of the Color Black. The children's resistance to black characters also could be understood in relation to their own preferences of color. While reading the book 인종이야기 를 해볼까? [Let's Talk about Race] [36], the teacher asked the children about their preference towards the colors black and white, and they demonstrated their inclination to the color white as follows:

\section{Children: 흰색! [White!!]}

Sam: White!

Teacher: 흰색이 좋아? 왜 흰색이 좋아? [White? Why?]

Sue: 왜냐하면 검은색은 너무 dark 하쟎아. 그래서 아무것도 볼 수 없쟎아. [Because black is so dark that I can't see anything.]

Teacher: 지미는 흰색이 왜 좋아? [What about you, Jimmy?]

Jimmy: (with a loud voice) because it might be.. when I am black, I will be dark and be back and kill people with swords. 
Teacher: 근데 왜 black people 은 killing people 할거 같아? [Why do you think that a black person will kill people with swords?]

Jimmy: (with a small voice) 왜냐면... black people 이.. 어.. swords 갖구 잘싸우니까 [Because.. black people fights well with swords.]

Duckitt et al. [66] argue that preschool children's preference for the color white is a product of society and history. In the excerpt above, most children showed their preference towards the color white, and it was not free from ideological discourse of color in their communities. For instance, Jimmy stated using English that he preferred the color white because the color black is related to something dangerous. For Jimmy, black is an unsafe color, so "being Black" provides the possibility to "kill people with swords." Sue also had a negative image towards the color black as being unsanitary and invisible. Like Jimmy and Sue, most of the children showed negative views to the color black, and this could influence their negative attitudes towards black characters.

Media Influence. The children's negative responses were also closely related to how the media have portrayed black people in US history. Stereotypes of black people are pervasive in American society [7]. Through radio, television, and films, African Americans have been depicted with negative stereotypes such as black males as "criminals," "oversexed," or "potential rapists" [67, page 179]. Park [42] also claims that blacks are often portrayed as being violent through the media based on white perspectives. In this situation, the children's responses could be affected by stereotypical images of blacks in media. For instance, Jimmy's view on blacks as "a good fighter" seemed to be influenced by his experiences with media, although Jimmy's mother stated that Jimmy was not specifically exposed to media that portrayed black people as being dangerous. The following is the conversation between Jimmy and the researcher about his experience of video game:

Researcher: 근데 Jimmy 는 black people 나오는 컴퓨 터 게임같은거 혹시 해? [Have you ever played video games?]

Jimmy: 음.. 나는 안해. 어 근데, 가끔 팀집에서 하는거 구경해. [Umm.. No I don't. But sometimes I watched Tim to play the game at his home.]

Researcher: 팀은 무슨 게임 하는데? [What does he play?]

Jimmy: (looking excited) Street fighter!!

Researcher: 거기 black people 나와? [Does it have any black characters?]

Jimmy: 응! (throwing fake punches in the air) 되게 잘 싸워. [Yep! He fights really well.]

In this conversation, Jimmy indicated that he sometimes watched his friend playing the video game, Street Fighter, at his friends' place. In regard to this video game, $67 \%$ of educators and parents said that violence is an issue, so it is inappropriate for young people [68]. Considering this,

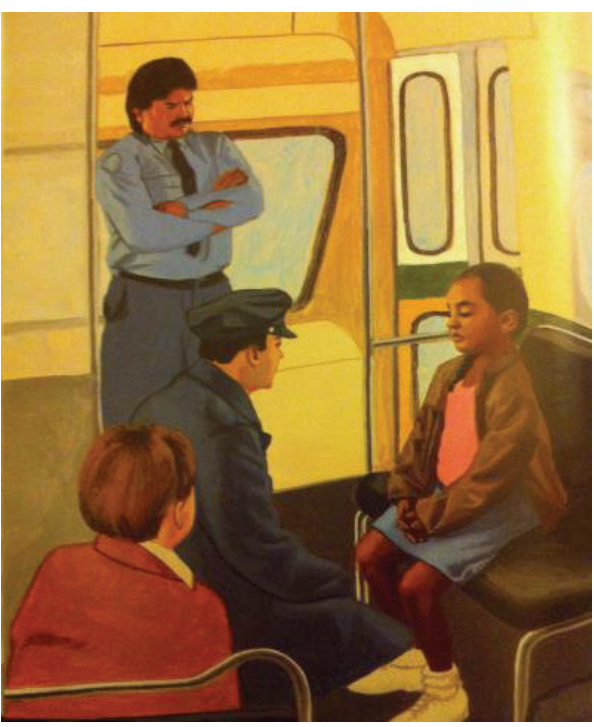

Figure 3: Police officers and Sarah in the bus.

Jimmy's stance towards black people as being dangerous could be related to his indirect exposure to black characters as aggressive street criminals in media.

2.3. Literature as Social Change. According to Sipe and McGuire [60], multicultural literature works as "a fertile ground for the examination of social inequalities and injustice" (page 10). In this study, race-themed picture books provided the children with a valuable opportunity to develop not only their literary understanding of the books but also their emergent notions of racial segregation, discrimination, and freedom.

Exploring the Notion of Racial Segregation. According to Young [69], racial segregation is the separation of humans into racial groups in some activities such as eating in a restaurant, using a public toilet, and attending school. The children in Ms. Park's classroom were able to explore the notion of racial segregation through race-themed picture books, and this was particularly evident when they read the book 사라, 버스를 타다 [Bus Ride]. This was a story about a young black girl (Sarah) who was not legally allowed to sit in the front seats of a bus. As children read about the bus driver stopping the bus and calling police for Sarah's refusal to go to the back of the bus, they seemed perplexed about the driver's action as no problem was evident (Figure 3). Noting that students were struggling to make sense of Sarah's situation, the teacher posed the following questions about the validity of Sarah's behavior:

Teacher: 지금 사라는 jail 에 갈 수도 있어. 근데 우 리는 어떻게 생각해? 사라가 잘못한거 같아? [Sarah can go to jail now. But, what do you think about it? Do you think that Sarah did wrong?]

Children: (thinking) 


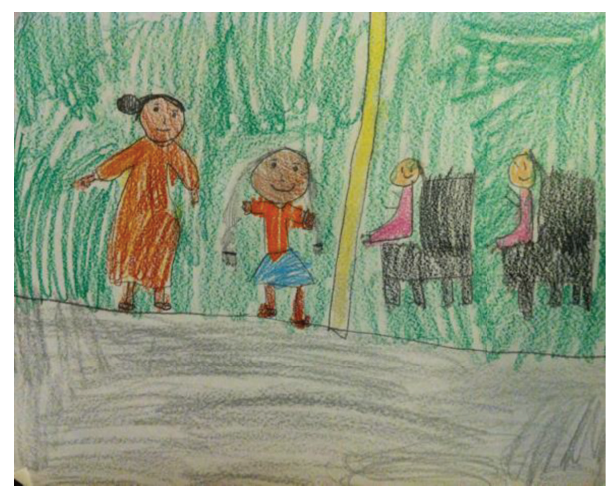

FIGURE 4: Sue's drawing about racial segregation in a bus.

Teacher: 우리 front seat 에 앉는건 나쁜 일이야? [Do you think that sitting in the front seats is a bad behavior?]

Some children: (shaking their heads negatively) No.

Teacher: 그치? 근데 사라는 front 에 앉으면 안됐어. 근데 왜? 왜 사라는 front seat 에 앉으면 안됐을까? [Right. But, Sarah was allowed to be seated only in the back. Why? Why was she not allowed to sit in the front of the bus?]

Young: Because she is a black.

Teacher: 그럼, 왜 black people 은 앞자리에 앉으면 안 되는데? Black people 은 무슨 문제 있는거야? [Then, why do you think black people were not allowed to be seated in the front? What is wrong with black people?]

In the excerpt above, the teacher asked the children many thought-provoking questions such as if sitting in the front seat of a bus gives logic to going to jail and why some acts are forbidden to black people. When the teacher described that black people were separated from white people in transportation, public accommodations, recreational facilities, and schools, the children attentively listened to the teacher's words. The children looked somewhat serious when the teacher asked questions to them about how they would feel when something is forbidden to them because of their skin colors. Such discussions helped the children develop their emergent notions about racial segregation and unfairness, and this was reflected in their drawings. Figure 4 is the example of children's written works about racial segregation.

In her drawing, Sue drew a picture of black people standing in the front and white people sitting in the back. She allowed only white people to sit, but she was positioning black people in the front: for Sue, sitting in the front is better than sitting in the back. When the researcher asked the reason for that, she indicated that she was positioning white people in the back in return for sitting on the chairs. By doing so, she attempted to provide advantages to both white and black people to make the situation fair.

Exploring the Notion of Freedom. Race-themed picture books also provided them with the opportunity to explore the notion of freedom. When reading 자유의 노래 [The Song of Freedom] [40], which dealt with the story of Martin Luther King and the African-American fight for civil rights, the children were able to think about the unfair treatment of slaves, why they were treated unjustly, and what it means to have freedom. The following is the conversation about freedom between the teacher and the children after reading the book:

Teacher: 그럼 자유 Freedom 이 뭔가 같아? [Then, what do you think freedom is?]

Jimmy: 음... black people 은 맘대로 노래 부를수 없구 식당도 따로 써야되구 근데 freedom 같은거.. 우리 아무것도 할수 있는거야. [Umm. Black people were not allowed to sing songs as they like, and they should use restaurant separately but.. with something like freedom, we can do anything.]

Teacher: 와 그렇구나. 다 할수 있는게 freedom 이 구나. [Wow. That is right. With freedom, you can do everything.]

Teacher: 또 딴사람은? 우리는 어떤 프리덤이 있지? [What about others? What kind of freedom do we have?]

Young: Free to play.

Sue: And free to buy anything. (with a loud and excited voice) And, And!! free to read books!

Katie: Freedom은 좋은 거예요. [Freedom is a good thing.]

Researcher: 왜? [Why?]

Katie: 응...(smiling) freedom 은 Happy 한거예요!! [Because.. freedom is happiness.]

When the children discussed freedom at the beginning of the study, they seemed to be confused with what it means (e.g., Young stated "freedom" might be the gas station "Freedom"). Yet, this time, their answers seemed more complicated and diverse. As they gained a better understanding of the meaning of freedom, students were able to apply the notion of freedom in their own contexts such as the "freedom to play" and "freedom to read books."

2.4. Possibility of Race-Themed Picture Books. During the semester, the children read a variety of picture books dealing with racial equality, discrimination, freedom, and racial diversity, and as the semester progressed their attitudes towards black characters started to change. For instance, when they read the book Chocolate Me! [37], Grace pointed out the benefits of having dark skin, saying "if you be dark, you protect your skin more.. better than white skin." Sam also argued the advantage of dark skin in both Korean and English as follows:

Sam: Dark skin 은 좋아요 [Dark skin is good]

Teacher: 왜? [Why?]

Sam: 음.. chocolate 같아요 [umm.. because it is like chocolate]. 


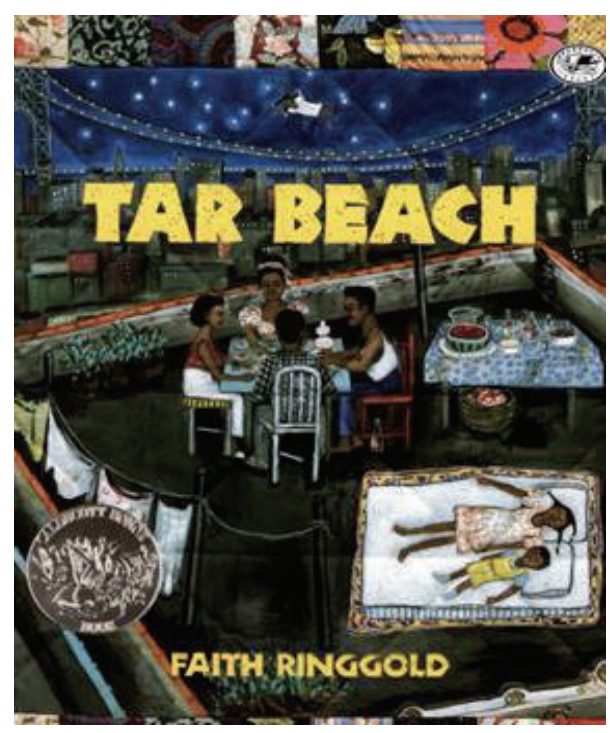

FIgUre 5: The cover of Tar Beach.

The teacher's positive views on multiculturalism and blacks also seemed to influence the children's changed attitudes towards blacks. During the observation period, the teacher often talked about the positive characteristics of black people, benefits of interracial friendships, and the beauty of the color black, and her positive attitudes towards blacks could influence the children's responses to black characters.

At the end of the semester, almost no student exhibited resistance towards African-American characters. It seemed that, for these children, a dark skin color was not a "weird" thing anymore. For example, when they read the book Tar Beach [39], the students had active discussions about a variety of issues including a Harlem rooftop, a starry night, city lights, and bridge, but nobody pointed out the main characters' dark skin (Figure 5).

When the children were asked about their views about black friends at the end of the semester, all children displayed their positive attitudes towards having black friends. For instance, Young indicated that although he had no black classmates in class, his black friends are "everywhere." Other children also indicated that they had black friends in their class or school as follows:

Sue: I have black friends in my class!!

Katie: Me too!!

Jimmy: I have two at school. We can be friends.

Sue was a child who often showed negative views towards black characters at the beginning of the semester. Yet, this time, she tried to brag with a smiling face about the fact that she has a black friend in her classroom. Jimmy also used to reveal strong resistance towards people with dark skin at the beginning. However, he started to open the possibility of making friends with two black classmates. Although there was an individual difference in terms of the degree of change, in general, the children's racial attitudes towards black people seemed to become more amiable. Figure 6 exhibits the total

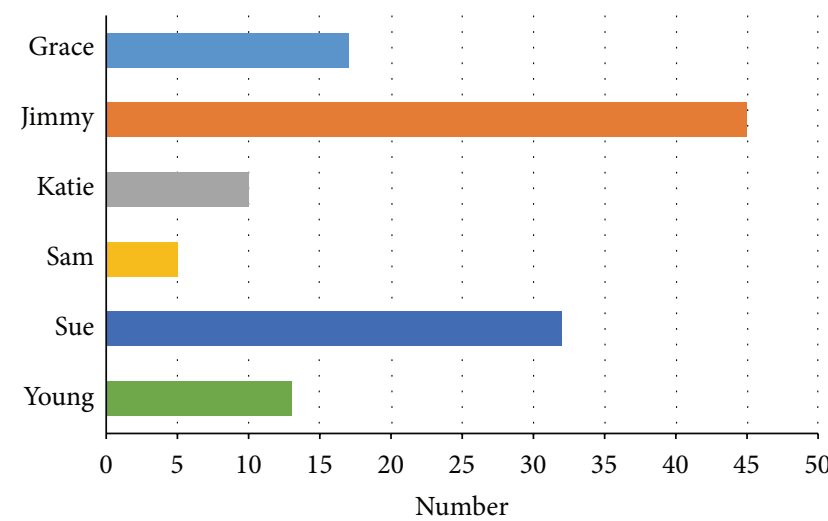

FIGURE 6: The total number of children's negative responses to black characters.

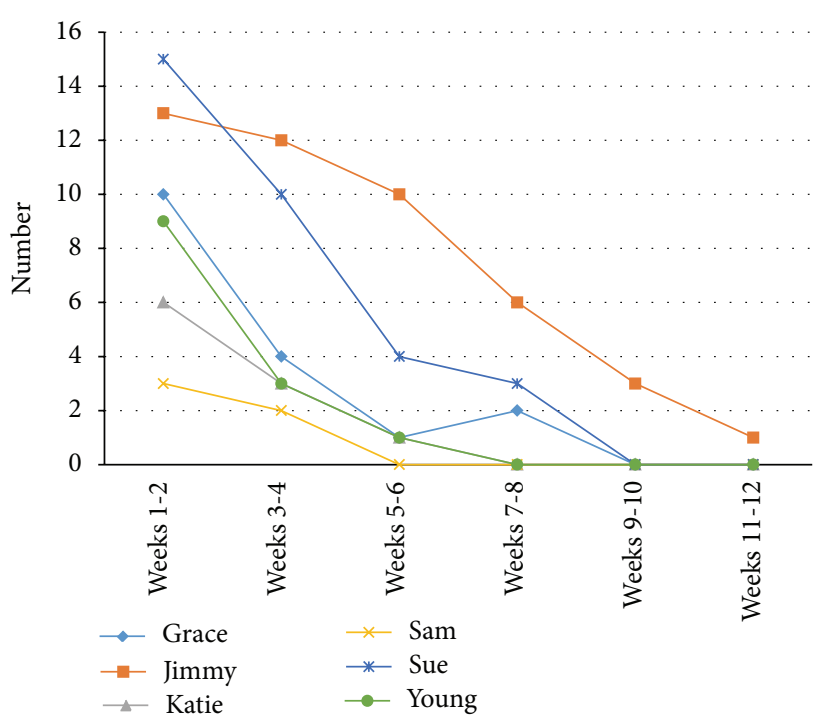

FIGURE 7: The change of children's negative responses to black characters.

number of children's negative responses to black characters during the semester and how it changed as the semester progressed.

Figures 6 and 7 indicate that the children's negative attitudes were visibly reduced as they were continuously exposed to the books that depicted African-American people. This was also supported by the interviews with the parents. Jimmy's mother indicated that Jimmy had no black friends at the beginning of the study. However, at the end of the semester, she indicated the following:

Jimmy's mother: Most times, he is still hanging out with Korean and white friends but, these days, it seems that he is getting along with other friends as well including black friends. Actually, a few days ago, Jimmy talked about his black friend in his school.

In the interview above, Jimmy's mother indicated that Jimmy seemed to open his mind to black friends. Ms. Park also indicated that the children seemed to be familiar with black children and started to open their minds to making 
friends with them as they consistently read books that had African Americans as main characters. She pointed out that that would be one of the greatest benefits of reading multicultural literature to young children:

Ms. Park: I think that one of the greatest benefits (of reading multicultural literature) is making diverse friends. I was surprised when Jimmy indicated he has black friends now. It seemed to me that the children's prejudice (to people with dark skin) was much reduced. They seemed to start to think that they should make friends not based on "color" or "image" but on personality. I think that they were able to open their minds (to black people) as they had chances to experience other people's lives through reading literature. Although those were indirect experiences, I think that that still provided the children with a valuable chance to experience other people's lives and open their minds to them.

As Ms. Park pointed out, picture books depicting African Americans and their culture provided the children with a chance to be familiar with blacks and to reduce their biased attitudes towards them. Through reading race-themed books, they also had the opportunity to learn about racial diversity, equality, discrimination, and segregation and to open their minds to making friends with other children regardless of skin color.

\section{Discussion}

This paper examined young Korean bilinguals' responses to African-American characters and the role of literary discussions about race-themed picture books. In this study, the children exhibited negative responses to black characters in the illustrations using both Korean and English, and their resistance to black characters reflected their allegiance to their social/cultural contexts such as their white-dominant surroundings and parents' negative racial views towards African Americans. Beach and Freedman [70] reclaim that students' literary responses are shaped by "cultural codes, attitudes and assumptions that constituting their experiences" (page 162). The way in which the children responded to books by bringing their diverse social and cultural experiences enhances reader response views that reading is not a solitary act but a complex social activity, shaped within social and cultural milieus.

Also, the findings of the study support the notion that racial and ethnic identities are not fixed entities but rather are socially constructed phenomena [71]. The children in this study were nonwhite, but some identified themselves as whites. According to Lei [72], "the White/Black binary" still serves "as normative racialized discourses in US society and educational research and practice" (page 85). Within the whiteness as norm and black as margin discourse, the children tried to include themselves in the same racial category as white people, and they even seemed to believe that they were in a higher position than black people. This finding challenges the prevalent notion of the "marginalization of minority student" (e.g., $[16,73,74])$. Although these children were "marginalized" in a mainstream US culture, they were also "marginalizing" other racial groups within the context of white privilege. The way in which the children were positioned in relation to whiteness supports the CRT notion that racism is an ingrained feature of racialized social systems and race is "something we do" rather than "something we are or have" [75, page 59].

The study also suggests the potential of race-themed picture books in bilingual contexts. According to Probst [76], the goal of reading literature is to provide students with a chance to learn not only about themselves but also about "human experience" (page 40). In this study, children became familiar with people of color and their cultures through the picture books. Race-themed picture books also provide opportunities for open discussions about racial justice issues including racial diversity, equality, and fairness. This finding suggests that literature that deals with race themes has the potential to help young children to "explore or envision possible selves, remember and revisit personal experiences" [77, page 168]. This could be especially helpful for children with limited exposure to racial and ethnic diversity.

In addition, the study suggests that literary talks using two languages can help young bilinguals to deepen their thoughts on literary texts and to develop their responses. While talking about books using both Korean and English, the children were able to express their thoughts about racial equality, discrimination, and segregation in a more comfortable atmosphere. They were also able to enjoy "the polyglossia of the texts" [78, page 66] and multiple voices while discussing the books by freely switching their languages. From this perspective, reading race-themed books using two languages plays a vital role for bilingual children in exploring diverse perspectives on different skin colors and having deeper layers of conversation about race.

3.1. Limitations of the Study. This study asserts the significance of race-themed picture books in young bilingual classroom. Yet, in making this claim, there were several limitations in this study. First, the results may not be applicable to children from different racial, cultural, and socioeconomic backgrounds. Thus, further research is needed in this area in different bilingual settings. Another limitation of this study is related to the difficulty of sharing ideas about race with the parents. Although the researcher gained the parents' trust through long-term relationships with them, some parents still seemed to try to hide their genuine feelings towards blacks due to the sensitivity of the issue.

The findings of this study may produce a level of discomfort to some people, but this study will provide teachers and educators with a chance to think about the importance of teaching racial/ethnic/cultural diversities in Pre-K children's classrooms, particularly in bilingual contexts. In addition, the detailed descriptions of the children's responses to the books using both Korean and English can illuminate the complexity of bilingual children's reading of literature in bilingual and bicultural contexts.

3.2. The Role of Teachers in a Multicultural Era. The findings of the study add significant insights into conversations related 
to teaching literature in young bilingual children's classrooms in several aspects. First, the social aspects of children's responses suggest that, in order to create more supportive literature environments for bilingual children, teachers should pay more attention to how their responses are shaped by their bilingual and bicultural surroundings. Because bilingual children' responses are created within different ideological discourses in bilingual and cultural frameworks, teachers need to understand their different social experiences in different cultural settings [19]. Also, it is important that teachers consider each child's differences and his/her different historical, societal, and cultural backgrounds [79].

Second, the way in which Ms. Park used the book as a tool to facilitate the discussions about race with preschool children suggests that the goal of a literature program in young children's classrooms has to be that students learn not only about literacy skills but also about dynamic human experiences. Bishop [7] argues that literature for young children is not simply an aesthetic literary work but a literary vehicle to help them develop their understanding of complex social issues. Thus, reading literature in young children's classrooms should be the first step to critically analyze all the "differences" that they meet in a racially, ethnically, and culturally diverse world [13]. To this end, it is crucial for teachers to help young children to be engaged in the story by facilitating literary talks about racial/ethnic/cultural diversity, using the examples that children can experience in their daily lives.

Third, this study suggests that, in order to help young bilingual children to grow up as participants of global communities, reading literature for bilingual children should be more than learning two language skills. Darder [17] argues that young bilinguals are exposed to different social norms and worldviews with their "bicultural identity" (page 324). Teaching two language/literacy skills is not enough to help young bilinguals fulfill their potential to live productive and empowered lives in an increasingly diverse society [16]. Thus, in order to help them grow up as democratic individuals, it is crucial to provide young bilingual children with a chance to openly discuss racial/ethnic/cultural diversities using two languages.

Lastly, teachers need to pay considerable attention to how minority children create their own racial concepts in their daily experiences. Racial concepts heavily influence children's cognitive, emotional, and social development $[23,56]$. In particular, race plays a critical role in minority children's language/literacy learning [50]. Since race is "a social fact in which the social and political significance of whiteness plays a critical role" [80, page 654], teachers should understand how the environmental and societal factors influence young bilingual children's perception and understanding of race and how subsuming notions of whiteness affects their literacy development.

My observations in Ms. Park's classroom began with my personal belief that all classrooms, including Pre- $K$ and bilingual classrooms, should be places that nurture a more just society. Young bilingual children are exposed to all kinds of differences in their everyday lives [16]. In order to create supportive literacy environments, reading literature with young bilingual children should be the first step in developing the critical attitudes needed in a democratic society [14]. When teachers create a safe space where bilingual children discuss real-life problems such as race, diversity, injustice, and unfamiliar cultures from an early age, they can grow up as active social agents who appreciate cultural, racial, and ethnic diversities that they experience in their daily lives.

\section{Conflict of Interests}

The author declares that there is no conflict of interests regarding the publication of this paper.

\section{References}

[1] M. Augoustinos and D. L. Rosewarne, "Stereotype knowledge and prejudice in children," British Journal of Developmental Psychology, vol. 19, no. 1, pp. 143-156, 2001.

[2] R. Sorin, "Validating young childrens feelings and experiences of fear," Contemporary Issues in Early Childhood, vol. 4, no. 1, pp. 80-89, 2003.

[3] A. Vuckovic, "Making the multicultural learning environment flourish: the importance of the child-teacher relationship in educating young children about diversity," Australian Journal of Early Childhood, vol. 33, no. 1, pp. 9-16, 2008.

[4] V. D. van Ausdale and J. R. Feagin, The First R: How Children Learn Race and Racism, Rowman \& Littlefield, Lanham, Md, USA, 2001.

[5] R. A. Eder, "Uncovering young children's psychological selves: individual and developmental differences," Child Development, vol. 61, no. 3, pp. 849-863, 1990.

[6] J. A. Banks, "History, characteristics, and goals," in Handbook of Research on Multicultural Education, J. A. Banks and C. A. M. Banks, Eds., pp. 3-29, John Wiley \& Sons, New York, NY, USA, 2004.

[7] R. S. Bishop, "Multicultural literature for children: making informed choices," in Teaching Multicultural Literature in Grade K-8, pp. 37-54, Christopher-Gordon Publishers, Norwood, Mass, USA, 1992.

[8] M. Cai, Multicultural Literature for Children and Young Adults: Reflections on Critical Issues, Greenwood, Westport, Conn, USA, 2002.

[9] V. J. Harris, “Children's literature depicting blacks," in Using Multiethnic Literature in the K-8 Classroom, V. J. Harris, Ed., pp. 21-58, Christopher-Gordon Publishers, Norwood, Mass, USA, 1997.

[10] J. S. MacPhee, ““That's not fair”: the white teacher's reports on white first graders' responses to multicultural literature," Language Arts, vol. 74, pp. 255-265, 1997.

[11] S. Nieto, Affirming Diversity: The Sociopolitical Context of Multicultural Education, Pearson, Boston, Mass, USA, 4th edition, 2004.

[12] G. S. Boutte, J. Lopez-Robertson, and E. Powers-Costello, "Moving beyond colorblindness in early childhood classrooms," Early Childhood Education Journal, vol. 39, no. 5, pp. 335-342, 2011.

[13] J. Copenhaver-Johnson, "Talking to children about race: the importance of inviting difficult conversations," Childhood Education, vol. 83, no. 1, pp. 12-22, 2006.

[14] C. Martiínez-Roldaàn, "Bilingual children's responses to multicultural literature on discrimination," The Dragon Lode, vol. 18, no. 2, pp. 17-23, 2000. 
[15] K. J. Moller, "Providing support for dialogue in literature discussions about social justice," Language Arts, vol. 79, no. 6, pp. 467-477, 2002.

[16] J. Cummins, Negotiating Identities: Education for Empowerment in a Diverse Society, California Association for Bilingual Education, Ontario, Calif, USA, 1996.

[17] A. Darder, "Buscando America: the contributions of critical Latino educators to the academic development and empowerment of Latino students in the U.S," in Multicultural Education, Critical Pedagogy, and Politics of Difference, C. E. Sleeter and P. L. McLaren, Eds., pp. 310-318, State University of New York Press, Albany, NY, USA, 1995.

[18] S. Fitts, L. Winstead, E. M. Weisman, S. Flores, and C. Valenciana, "Coming to voice: preparing bilingual-bicultural teachers for social justice," Equity \& Excellence in Education, vol. 41, no. 3, pp. 357-371, 2008.

[19] O. Garcia and J. A. Kleifgen, Educating Emergent Bilinguals, Teachers College, New York, NY, USA, 2010.

[20] L. H. Quach, O. Ji-Yeon, and L. Urrieta, "Understanding the racialized identities of Asian students in predominantly white schools," in Race, Culture, and Identities in Second Language Education, R. Kubota and A. Lin, Eds., pp. 101-107, Routledge, New York, NY, USA, 2009.

[21] S. Marx, "It's not them; it's not their fault': manifestations of racism in the schooling of Latinas/os and ELLs," in Race, Culture, and Identities in Second Language Education, R. Kubota and A. Lin, Eds., pp. 81-98, Routledge, New York, NY, USA, 2009.

[22] S. Brown, M. Souto-Manning, and T. T. Laman, "Seeing the strange in the familiar: unpacking racialized practices in early childhood settings," Race Ethnicity and Education, vol. 13, no. 4, pp. 513-532, 2010.

[23] R. Rogers and M. Mosley, "Racial literacy in a second-grade classroom: Critical race theory, whiteness studies, and literacy research," Reading Research Quarterly, vol. 41, no. 4, pp. 462495, 2006.

[24] R. Hu and M. Commeyras, "A case study: emergent biliteracy in english and Chinese of a 5-year-old Chinese child with wordless picture books," Reading Psychology, vol. 29, no. 1, pp. 1-30, 2008.

[25] I. Reyes and P. Azuara, "Emergent biliteracy in young Mexican immigrant children," Reading Research Quarterly, vol. 43, no. 4, pp. 374-398, 2008.

[26] D. B. Yaden Jr. and J. Tardibuono, “The emergent writing development of urban, Latino preschoolers: developmental perspectives and instructional environments for second language learners," Reading \& Writing Quarterly: Overcoming Learning Difficulties, vol. 20, no. 1, pp. 29-62, 2004.

[27] C. Park, Myth of Pure-Blood Nationalism Blocks Multi-Ethnic Society, 2006, http://rosesnchaos.livejournal.com/244176.html.

[28] Korean Statistical Information Service, "Population and household," 2010, http://kosis.kr/.

[29] J. Twomey, "Koreans and Blacks in America: a brief pre-riot history to the 1992 Los Angeles Riot," in Socio-Cultural Conflicts between African American and Korean American, M. K. Asante and E. Min, Eds., pp. 25-34, University Press of America, Lanham, Md, USA, 2000.

[30] E. Min, "Blues and Haan: discourses of despair and lamentation of African American and Korean American: an introduction," in Socio-Cultural Conflicts between African American and Korean American, M. K. Asante and E. Min, Eds., pp. 1-12, University Press of America, Lanham, Md, USA, 2000.
[31] H.-W. Kim, "Public opinions and current situations concerning early study-abroad," in Proceedings of the 26th KEDI Educational Policy Forum, Seoul, Republic of Korea, 2005.

[32] Korean Joong-ang Daily, "English teacher assaults 61-yearold man on bus," http://koreajoongangdaily.joinsmsn.com/ news/article/html/934/2940934.html.

[33] D. D. Han, "An African American English teacher at an English village in Daejeon posts a sex video online," 2010, http://news .hankooki.com/lpage/society/201010/h2010100817233621950 .htm.

[34] M. Hoffman, Original: Amazing Grace (1991), Si-gong Junior, Seoul, South Korea, 2005.

[35] E. Levin, Original: Henry's Freedom Box (2007), D-in-dol Children, Seoul, Republic of Korea, 2008.

[36] J. Lester, Original: Let's Talk about Race (2005), Four Season, Seoul, Republic of Korea, 2007.

[37] T. Diggs, Chocolate Me!, Feiwel and Friends, New York, NY, USA, 2011.

[38] W. Miller, Original: The Bus Ride (2001), Four Season, Seoul, Republic of Korea, 2004.

[39] F. Ringgold, Tar Beach, Random House, New York, NY, USA, 1991.

[40] M. H. Kang, The Song of Freedom, Yangchulbook, Seoul, Republic of Korea, 2009.

[41] M. F. Asante, "African American and Korean Americans: modeling the American dream," in Socio-Cultural Conflicts between African American and Korean American, M. K. Asante and E. Min, Eds., pp. 13-24, University Press of America, Lanham, Md, USA, 2000.

[42] K. Park, The Korean American Dream: Immigrants and Small Business in New York City, Cornell University Press, New York, NY, USA, 1997.

[43] R. Kubota and A. Lin, "Introduction," in Race, Culture, and Identities in Second Language Education, R. Kubota and A. Lin, Eds., pp. 1-23, Routledge, New York, NY, USA, 2009.

[44] R. Beach, "Constructing cultural models through response to literature," The English Journal, vol. 84, no. 6, pp. 87-94, 1995.

[45] D. Bleich, "Reading as membership," ADE Bulletin, vol. 102, pp. 6-10, 1992.

[46] J. Culler, Literacy Theory, Sterling Publishing, New York, NY, USA, 1997.

[47] R. Beach, "New direction in research on response to literature," in Transactions with Literature: A Fifty-Year Perspective, E. J. Farrell and J. R. Squire, Eds., pp. 65-77, National Council of Teachers of English, Urbana, Ill, USA, 1990.

[48] C. Compton-Lilly, "Counting the uncounted: African American students in reading recovery," Journal of Early Childhood Literacy, vol. 11, no. 1, pp. 3-24, 2011.

[49] D. Gillborn, "Critical race theory and education: racism and anti-racism in educational theory and praxis," Discourse: Studies in the Cultural Politics of Education, vol. 27, no. 1, pp. 11-32, 2006.

[50] T. Liggett, "The mapping of a framework: critical race theory and TESOL," Urban Review, vol. 46, no. 1, pp. 112-124, 2014.

[51] R. D. Goodman and C. A. West-Olatunji, "Educational hegemony, traumatic stress, and african american and latino american students," Journal of Multicultural Counseling and Development, vol. 38, no. 3, pp. 176-186, 2010.

[52] G. Shuck, "Racializing the nonnative english speaker," in Journal of Language, Identity, and Education, T. Ricento and T. G. Wiley, Eds., Lawrence Erlbaum Associates, Mahwah, NJ, USA, 2006. 
[53] A. Curtis and M. Romney, Eds., Color, Race, and English Language Teaching: Shades of Meaning, Lawrence Erlbaum Associates, Mahwah, NJ, USA, 2006.

[54] R. Kubota, "Critical multiculturalism and second language education," in Critical Pedagogies and Language Learning, B. Norton and K. Toohey, Eds., pp. 30-52, Cambridge University Press, Cambridge, UK, 2004.

[55] C. Prendergast, Literacy and Racial Justice: The Politics of Learning after Brown v Board of Education, Southern Illinois University Press, Carbondale, Ill, USA, 2003.

[56] G. van de Kleut, "The whiteness of literacy practice in Ontario," Race Ethnicity and Education, vol. 14, no. 5, pp. 699-726, 2011.

[57] J. Creswell, Qualitative Inquiry and Research Design: Choosing among Five Traditions, Sage, Thousand Oaks, Calif, USA, 1998.

[58] R. Emerson, R. Fretz, and L. Shaw, Writing Ethnographic Fieldnotes, University of Chicago Press, Chicago, Ill, USA, 1996.

[59] C. Y. Park, Maintaining Korean as a heritage language [unpublished doctoral dissertation], Arizona State University, Phoenix, Ariz, USA, 2007.

[60] L. R. Sipe and C. E. McGuire, "Young children's resistance to stories," Reading Teacher, vol. 60, no. 1, pp. 6-13, 2006.

[61] L. R. Sipe, Storytime: Young Children's Literary Understanding in the Classroom, Teachers College, New York, NY, USA, 2008.

[62] S. Hughes-Hassell, H. A. Barkley, and E. Koehler, "Promoting equity in children's literacy instruction: using a critical race theory framework to examine transitional books," School Library Media Research, vol. 12, 2009, http://www.ala .org/aasl/sites/ala.org.aasl/files/content/aaslpubsandjournals/ slr/vol12/SLMR_PromotingEquity_V12.pdf.

[63] H. A. Giroux, "Rewriting the discourse of racial identity: towards a pedagogy and politics of whiteness," Harvard Educational Review, vol. 67, no. 2, pp. 285-320, 1997.

[64] Z. Leonardo, "The race for class: reflections on a critical raceclass theory of education," Educational Studies, vol. 48, pp. 427-449, 2012.

[65] M. Fix and J. S. Passel, "U.S. immigration-trends and implications for schools," in Paper Presented at the Meeting of the National Association for Bilingual Education NCLB Implementation Institute, New Orleans, La, USA, 2003.

[66] J. Duckitt, C. Wall, and B. Pokroy, "Color bias and racial preference in White South African preschool children," The Journal of Genetic Psychology, vol. 160, no. 2, pp. 143-154, 1999.

[67] L. T. Fishman, "The black bogeyman and white self-righteousness," in Images of Color Images of Crime, C. R. Mann and M. S. Zatz, Eds., pp. 177-191, Roxbury Publishing Company, Los Angeles, Calif, USA, 2002.

[68] Common Sense Media, Super Street Fighter IV: Arcade Edition, 2012, http://www.commonsensemedia.org/game-reviews/ super-street-fighter-iv-arcade-edition.

[69] I. M. Young, Justice and the Politics of Difference, Princeton University Press, Princeton, NJ, USA, 1990.

[70] R. Beach and K. Freedman, "Responding as a cultural act: adolescents' responses to magazine ads and short stories," in Reader Stance and Literary Understanding, J. Many and C. Cox, Eds., pp. 162-190, Alex, Norwood, NJ, USA, 1992.

[71] L. M. Burton, E. Bonilla-Silva, V. Ray, R. Buckelew, and E. H. Freeman, "Critical race theories, colorism, and the decade's research on families of color," Journal of Marriage and Family, vol. 72, no. 3, pp. 440-459, 2010.

[72] J. L. Lei, "Teaching and learning with Asian American and Pacific Islander students," Race Ethnicity and Education, vol. 9, no. 1, pp. 85-101, 2006.
[73] M. Minami, "Crossing borders: the politics of schooling Asian students," in The Politics of Multiculturalism and Bilingual Education: Students and Teachers Caught in the Cross Fire, C. J. Ovando and P. McLaren, Eds., pp. 188-207, McGraw-Hill, New York, NY, USA, 2000.

[74] A. C. Willig, "Special education and the culturally and linguistically different child: an overview of issues and challenges," in Bilingualism and Learning Disabilities, A. C. Willig and H. F. Greeberg, Eds., pp. 191-210, American Library Publishing, Asbury Park, NJ, USA, 1986.

[75] V. A. Moore, “The collaborative emergence of race in children's play: a case study of two summer camps," Social Problems, vol. 49, no. 1, pp. 58-78, 2002.

[76] R. E. Probst, "Reader-Response theory and the English curriculum," English Journal, vol. 83, no. 3, pp. 37-44, 1994.

[77] K. J. Möller and J. Allen, "Connecting, resisting, and searching for safer places: students respond to Mildred Taylor's the friendship," Journal of Literacy Research, vol. 32, no. 2, pp. 145$186,2000$.

[78] B. Corcoran, "Reader stance: from willed aesthetic to discursive construction," in Reader Stance and Literary Understanding, J. Many and C. Cox, Eds., pp. 49-74, Alex Publishing Corporation, Norwood, NJ, USA, 1992.

[79] C. Genishi and A. Dyson, Children, Language, and Literacy: Diverse Learners in Diverse Times, Teachers College Press, 2009.

[80] T. J. Guess, "The social construction of whiteness: racism by intent, racism by consequence," Critical Sociology, vol. 32, no. 4, pp. 649-673, 2006. 

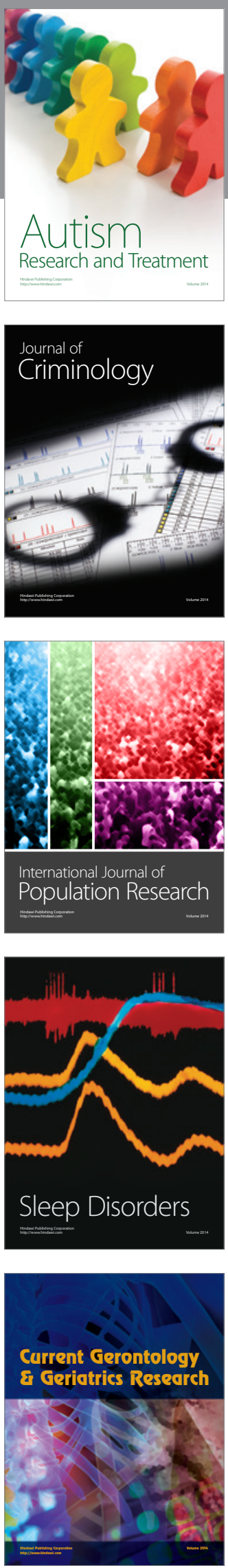
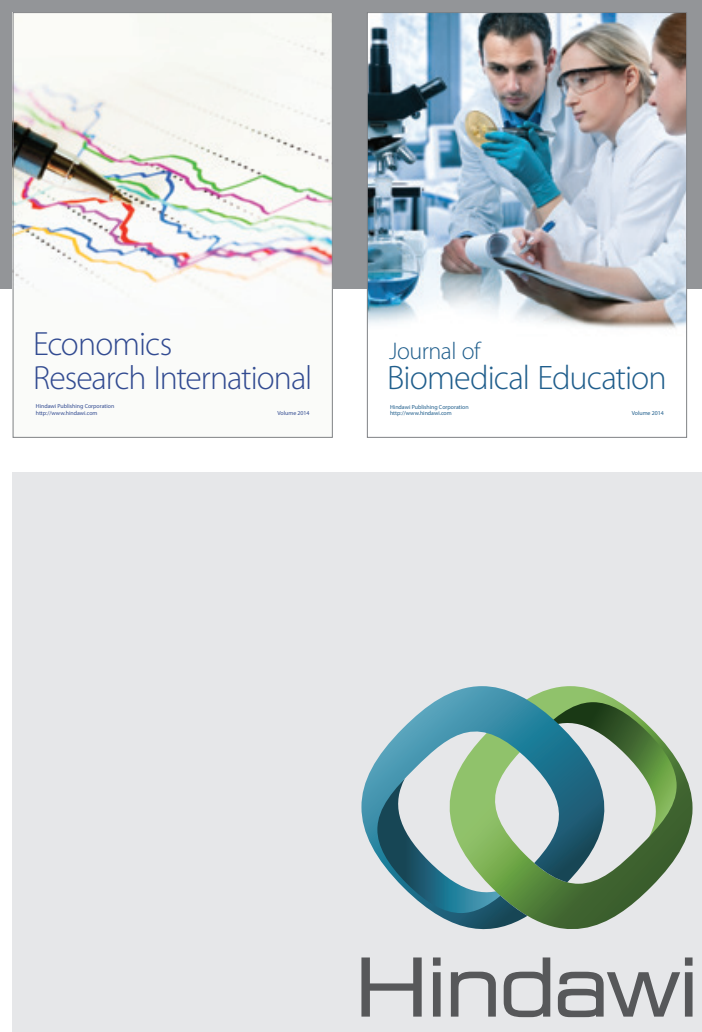

Submit your manuscripts at

http://www.hindawi.com
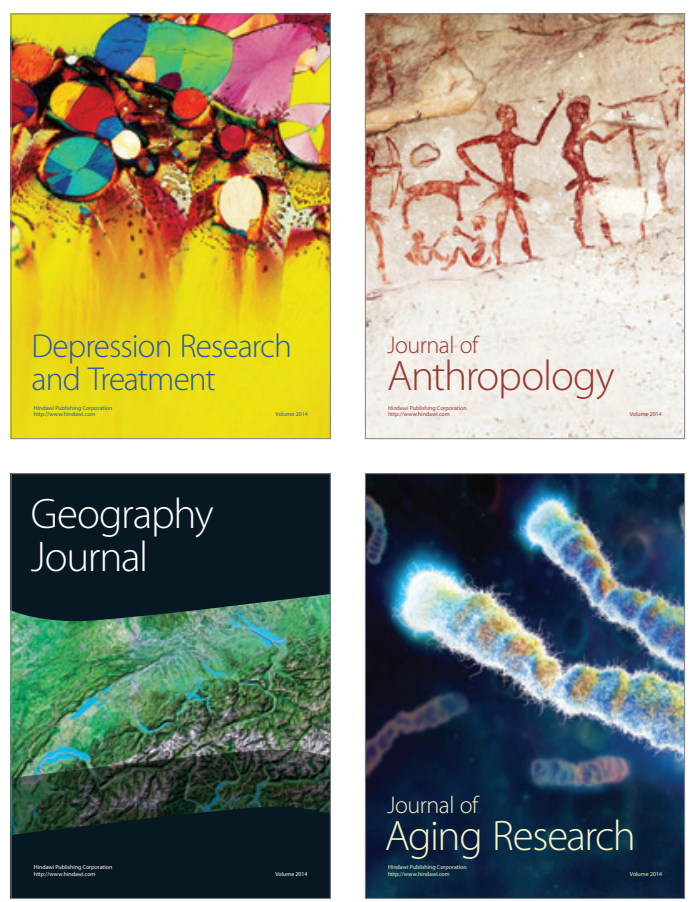
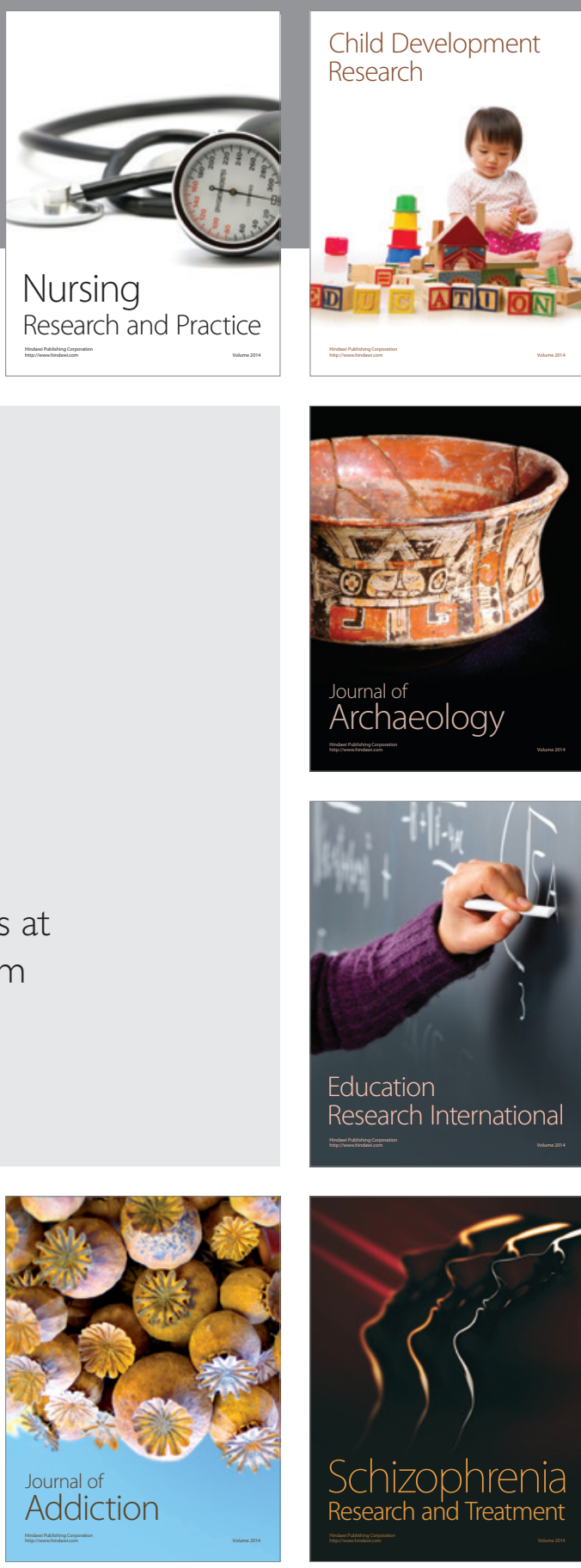

(D)
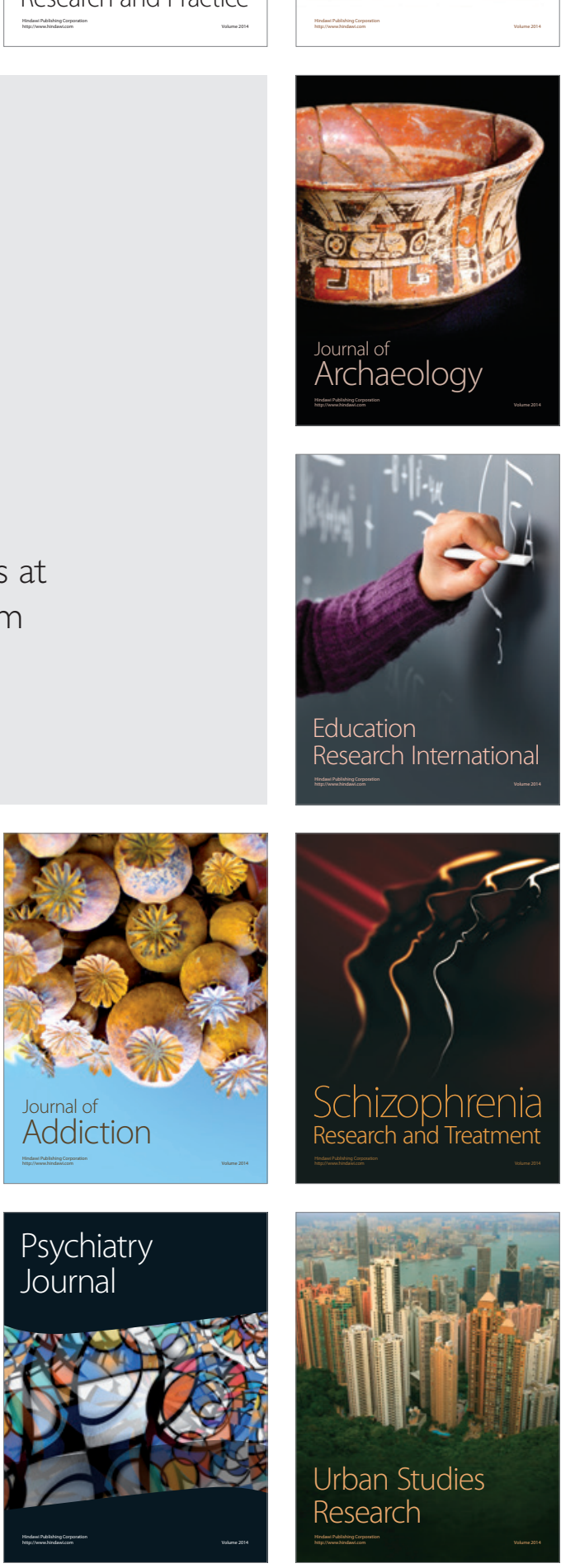